\title{
Evaluating the Information Needs of Home-based and Cross-border Distance Learners in Botswana
}

\author{
Olugbade Oladokun \\ University of Botswana, Botswana
}

\begin{abstract}
Given the fact that there was only one public university in Botswana until recently when the second was established, it became impossible for the nation to meet the educational needs of its people through face-to-face system. The bid to expand the accessibility of citizens to further education led to the search for the option found in distance education. The study investigated the information needs of the students of four distance teaching institutions in Botswana. The institutions include the University of Botswana $(U B)$ regarded here as home-based and three cross-border institutions (University of Derby (UD), University of South Africa (UNISA) and Management College of Southern (MANCOSA) that had visible presence in the country. UD and MANCOSA operate higher degree programmes, UB runs undergraduate, while UNISA operates both undergraduate and post graduate programmes. In addressing the objectives of the study, a survey method was employed using questionnaire administered to 519 distance learners of 4 tertiary distance teaching institutions in the country that met the criteria set. With 364 copies of the questionnaire duly completed and returned, $70.1 \%$ response rate was generated. The findings established the information need areas of distance learners and means of meeting their needs. The study revealed the extent to which the learners' information needs were met.
\end{abstract}

\section{Introduction}

Education is given a high premium in the national agenda of Botswana. But given the fact that there was only one public university in the country for a long time (the second has only recently been established), it became impossible for the nation to meet the educational needs of its people through face-to-face classroom-bound system. The other option was found in distance education - some homebased, others trans-national. Distance education in Botswana is particularly significant for those in

employment, the less privileged and, or the disadvantaged who may wish to take a second chance at educating themselves. As such the only public university in the country had to go dual-mode, even as trans-national distance education also thrives.

This study investigated the information needs of distance education students at tertiary-level in Botswana. Four distance teaching institutions comprising the University of Botswana (UB) herein referred to as home-based and three cross-border distance teaching institutions namely: University of Derby (UD), University of South Africa (UNISA) and Management College of Southern Africa (MANCOSA), that had visible presence in the country were focused.

\section{Literature review}

Commonwealth of Learning [1] asserts that the basic information services that distance learners need are access to information resources, such as texts, supplementary reading and reference services; learning how to find the information they need from the information that is available and developing ways to apply the information gleaned and to make sound, information-based decisions. Singh [2] also argues that distance learners generally need some of the following types of information services, namely the loan of a specific book, reference book usually one referred to in their SIMs; a photocopy of a specific journal article or single chapter of a book; a photocopy of previous examination papers for their course; information / material on a particular subject; self Instructional materials; viewing and listening to audio-visual materials; using the different type of library collection; and using equipment and facilities available.

While examining the information needs of continuing education students, Oladokun and Aina [3] affirm subjects relating to their course of study (95\%), on job opportunities (89\%), information on career development (84\%) and information on sponsorship or scholarships for further education (80\%), as important areas of information need. Similarly, in their investigation of the Sandwich and Part-Time Students of Two Public Universities in Nigeria Adesoye and Amusa [4], note that the information needs of the respondents are diverse and vary from information on their course of study, and 
career development, to information on current affairs and politics.

Rowland and Rubbert [5] study shows that the information needs and practices of part-time, distance-learning and mature students in a lifelong learning environment have been rapidly transformed by the use of ICT in the higher education sector. They observe that even though electronic facilities make information gathering easier for part-time and distance-learning students, there is still a long way to go until institutional information services are optimised in the HE sector. Oladokun [6] also alludes to the study in India of Jagannathan [7], where she categorised distance students information requirements into three. First, she asserts the Need for materials and facilities: which she notes includes several kinds of materials such as reference books, texts books, journals, reports, Self-Instructional Materials (SIMs). Second, is the need for information services such as bibliographic instruction for print and non-print materials; information about distance learning agencies, and support services. The third is the need for user services comprising professional guidance and support from the library staff about using library collection, using equipment and facilities available at the library. This study attempts to evaluate the information needs of both the home-based and crossborder distance learners in Botswana.

\section{Methodology}

In addressing the objective of the study, a survey method was employed with a self administered questionnaire subjected to a pilot study Altogether the questionnaire was administered to 519 distance learners of the four tertiary distance teaching institutions in the country that met the criteria set. With 364 copies of the questionnaire duly completed and returned, $70.1 \%$ response rate was generated. The Statistical Package for Social Sciences (SPSS) was employed for computational analysis and standard statistics were used, including frequency distributions and percentages, to carry out the analysis. Cross tabulation and chi-square (nonparametric) were made to relate the independent variables under demographic information to the findings and establish or measure possible influence where appropriate

\section{Findings}

The study sets out to identify the information needs of distance learners in Botswana. In addressing the objective, a number of questions were raised with the respondents. In the reaction from the options offered, it became obvious to note that 'subjects relating to their course of study' ranks the highest in the information needs area, with 273 (75\%) respondents. With $218(60 \%)$ respondents, the thirst to acquire greater skill in the use of information and communication technologies e.g. the Internet was seen as the second priority need area. The remaining information need areas indicated by about half of respondents include information on Tests, examinations and residential sessions/periods $(51.6 \%)$ and the Development of information searching skills (50.8 percent).

The information need areas (in a descending order) that attracted less than half of the total respondents include: Access to a help line (41.2\%), Making information-based decisions (31.3\%); and the Need for specialized information was the least with 29.7 percent in its favour. Figure 1 below presents a more graphic display of the distance learners' view of their information needs in Botswana.

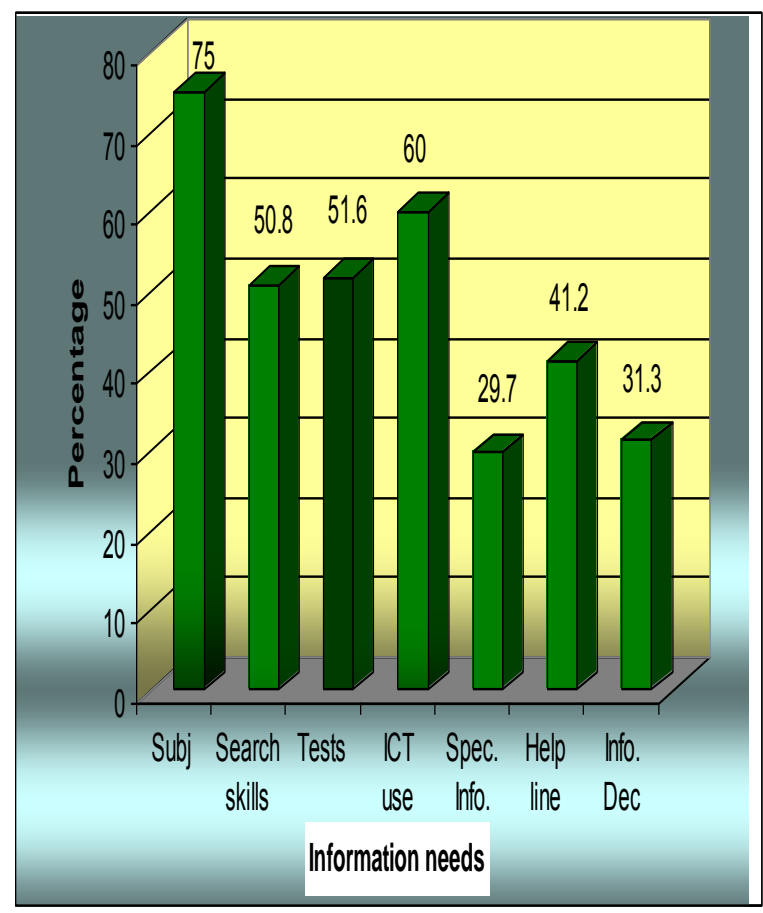

Figure 1: Information Needs Areas

In order to further ascertain the information needs of the distance learners, another question to determine the reasons the respondents would require information was raised. With the options provided, $283(77.7 \%)$ the respondents indicated 'yes' they would require information to write assignment, 80 of them $(22.0 \%)$ said 'no'. To study and prepare for test and examination, $273(75 \%)$ said 'yes', 90 of them $(24.7 \%)$ said 'no'. For coursework-related information needs, $244(67 \%)$ respondents indicated 'yes', while 119 (32.7\%) said 'no'. Another 152 $(41.8 \%)$ indicated 'yes' to the option of borrowing books, whilst 211 or $58 \%$ indicated 'no'. 
An attempt was made to check whether the institutions of respondents have any relationships with the information need areas by cross-tabulating the variables and performing chi-square tests. Table 1 indicates that institution was significantly related to information needs in a number of areas, namely: "subjects relating to their course of study" $\left(\mathrm{X}^{2}=\right.$ 9.092, df $=3, \mathrm{p}<.05)$; "development of information search skills" ( $\left.\mathrm{X}^{2}=16.981, \mathrm{df}=3, \mathrm{p}<.05\right)$; "tests, examinations and residential sessions/periods" $\left(\mathrm{X}^{2}=\right.$ $66.803, \mathrm{df}=3, \mathrm{p}<.05)$; "access to a help line" $\left(\mathrm{X}^{2}=\right.$ 8.332 , df $=3, \mathrm{p}<.05)$ and "making informationbased decisions" ( $\mathrm{X}^{2}=8.192$, $\left.\mathrm{df}=3, \mathrm{p}<.05\right)$. No significant difference was found between the institutions in the other information needs areas. The implication of the findings is that all the areas mentioned above are significantly desirable information need areas of distance learners in Botswana.

Table 1: Relationship between Institution and Information needs

\begin{tabular}{|l|l|l|l|l|}
\hline $\begin{array}{l}\text { Information Needs } \\
\text { Areas }\end{array}$ & $\begin{array}{l}\text { Chi- } \\
\text { square }\end{array}$ & Df & $\begin{array}{l}\text { Asymp } \\
\text {. Sig. } \\
\mathbf{( 2 -} \\
\text { sided) }\end{array}$ & Remark \\
\hline $\begin{array}{l}\text { Subjects relating to } \\
\text { their course of } \\
\text { study }\end{array}$ & 9.092 & 3 & .028 & Significant \\
\hline $\begin{array}{l}\text { Development of } \\
\text { information search } \\
\text { skills }\end{array}$ & 16.981 & 3 & .001 & Significant \\
\hline $\begin{array}{l}\text { Tests, examinations } \\
\text { and residential } \\
\text { sessions/ periods }\end{array}$ & 66.803 & 3 & .000 & Significant \\
\hline $\begin{array}{l}\text { Use of ICT } \\
\text { Others }\end{array}$ & 8.490 & 3 & .213 & $\begin{array}{l}\text { Not } \\
\text { significant }\end{array}$ \\
\hline $\begin{array}{l}\text { Need for } \\
\text { specialized info }\end{array}$ & 5.072 & 3 & .167 & $\begin{array}{l}\text { Not } \\
\text { significant }\end{array}$ \\
\hline $\begin{array}{l}\text { Access to a help } \\
\text { line }\end{array}$ & 8.332 & 3 & .040 & Significant \\
\hline $\begin{array}{l}\text { Making info based } \\
\text { decisions }\end{array}$ & 8.192 & 3 & .042 & Significant \\
\hline & 6.190 & $\begin{array}{l}\text { Not } \\
\text { significant }\end{array}$ \\
\hline
\end{tabular}

Table 2 below shows the observed and expected counts in the cross-tabulation of the Institutions (as a variable) and the information need area of "subjects relating to course of study" Comparison of the observed with the expected counts shows that the observed values are significantly different from the expected values. Invariably, the cross tabulation also works for cross-border and home-based distance students. More respondents from the UB, MANCOSA and UD than expected indicated 'yes' - they needed information on subjects relating to course of study. By contrast, less respondents, from UNISA, than expected said 'yes' The finding seems to suggest that a significant majority of distance learners across the institutions yearn for information on subjects relating to their courses of study. There also appears to be a correlation between home-based distance learners and the cross-border students represented by MANCOSA and UD in so far as this information need area is concerned. Similarly, a comparison of the observed and the expected counts (in Table 3) shows that the expected values are significantly different from the observed values. More respondents than expected in UB, MANCOSA and UD would say 'yes' to development of information search skills, as an information need area. It was only in UNISA again that less respondents than expected said yes. These findings show that a lot of importance was attached to information searching skills development as an information need area by the cross-border respondents pursuing higher degree programmes. The choice of this information need by more crossborder respondents underscored the importance of research which the students at higher degree level probably have to engage in with the information search skills. Interestingly the choice compared significantly well with the desire of home-based distance learners too, all of whom enrolled for degree programme. This finding could also be a signal that the UNISA package, unlike UB's, was self-sufficient and that it (UNISA) did not require the need for its students to carry out so much research or use any other resources outside the (self sufficient) package given to them for each course.

When a comparison of the observed and the expected counts is drawn on "Tests, examinations and residential sessions/periods" as information need area (Table 4), the results fall into different significant values. In MANCOSA and UD, less respondents than expected responded in the affirmative; whereas, more respondents than expected said 'yes' in UB, while the expected and the observed were almost the same in UNISA. These findings show that the respondents from higher degree institutions (MANCOSA and UD) did not have much problem with the information need area; hence, it was not a priority area. The result also seems to mark the difference in the maturity of learners in the category of respondents pursuing higher degree programmes and those enrolled for degree programmes. Usually, apart from writing tests and examinations, tutorials are held during the residential sessions. Respondents from MANCOSA and UD (cross-border and higher degree pursuing respondents) seemed not to be too enthusiastic on the residential sessions unlike the home-based (UB) degree pursuing respondents. Possibly because of the few higher degree pursuing respondents involved 
from UNISA, there was a semblance of equality in the expected and the observed values on the information need area. This result tends to show that the respondents who registered for postgraduate programmes are better disposed to or equipped for distance education mode as the findings show that fewer of them than expected indicated interest in residential session as a priority information need area.

Table 5 shows the expected and observed counts in the cross-tabulation of the Institution and access to a help line as an information need. Comparison of the observed with the expected counts shows that the observed values are significantly different from the expected values, and that more respondents than expected from the UB, UNISA and MANCOSA said 'yes' to "access to a help line" would constitute a significant information needs area to them, while less respondents than expected from the University of Derby said 'yes'. The conclusion, therefore, is that there is a significant relationship between the institution and access to a help line. The finding seems to suggest that the University of Derby probably makes better information and access provision for its students than other institutions (including the home-based institution) involved in the study.

In Table 6 a comparison of the observed with the expected counts shows that the observed values are significantly different from the expected values in the information needs area of making informationbased decisions. The findings show two significant divisions between the cross-border higher degree pursuing respondents (MANCOSA and UD) and predominantly degree pursuing respondents from UB (home-based) and UNISA (cross-border). The results show that in MANCOSA and UD more respondents than expected said 'yes' to making informationbased decisions, while in the UB and UNISA less respondents than expected said 'yes'. The conclusion, therefore, is that there is a significant relationship between the institutions and the information needs area of making information-based decisions. The finding seems to corroborate the possibility that higher degree pursuing (MANCOSA and UD) respondents tend to have inclination to making information-based decisions than the degree enrolled respondents.
Table 2: Relationship between Institution and Information needs area: Subject relating to course of study

\begin{tabular}{|c|c|c|c|c|c|}
\hline \multicolumn{6}{|l|}{ Crosstab } \\
\hline & & \multicolumn{2}{|c|}{$\begin{array}{l}\text { Information needs area - } \\
\text { Subject relating to study }\end{array}$} & \multirow[b]{2}{*}{ Total } & \multirow{2}{*}{$\begin{array}{l}\% \text { of } \\
\text { Total }\end{array}$} \\
\hline Institutions & & Yes & No & & \\
\hline \multirow[t]{2}{*}{\begin{tabular}{|l|l}
$\begin{array}{l}\text { UB } \\
\text { (Home- } \\
\text { based) }\end{array}$ \\
\end{tabular}} & Count & $\mathbf{7 8}(79.6 \%)$ & $\mathbf{2 0}(20.4 \%)$ & 98 & 26.9 \\
\hline & $\begin{array}{l}\text { Expected } \\
\text { Count }\end{array}$ & $\mathbf{7 3 . 5}(75 \%)$ & $\mathbf{2 4 . 5}(25 \%)$ & 98.0 & 26.9 \\
\hline \multirow[t]{2}{*}{$\begin{array}{l}\text { UNISA } \\
\text { (Cross- } \\
\text { border) }\end{array}$} & Count & $107(67.7 \%$ & $\mathbf{5 1}(32.3 \%)$ & 158 & 43.4 \\
\hline & $\begin{array}{l}\text { Expected } \\
\text { Count }\end{array}$ & $118.5(75 \%$ & $\mathbf{3 9 . 5}(25 \%)$ & 158.0 & 43.4 \\
\hline \multirow[t]{2}{*}{$\begin{array}{l}\text { MANCOS } \\
\text { A } \\
\text { (Cross- } \\
\text { border) } \\
\end{array}$} & Count & 39(86.7\%) & $\mathbf{6}(13.3 \%)$ & 45 & 12.4 \\
\hline & $\begin{array}{l}\text { Expected } \\
\text { Count }\end{array}$ & 33.8 $(75 \%)$ & $11.3(25 \%)$ & 45.0 & 12.4 \\
\hline \multirow[t]{2}{*}{$\begin{array}{l}\text { UD } \\
\text { (Cross- } \\
\text { border) }\end{array}$} & Count & $\mathbf{4 9}(77.8 \%)$ & $\mathbf{1 4}(22.2 \%)$ & 63 & 17.3 \\
\hline & $\begin{array}{l}\text { Expected } \\
\text { Count }\end{array}$ & $\mathbf{4 7 . 3}(75 \%)$ & $15.8(25 \%)$ & 63.0 & 17.3 \\
\hline \multirow[t]{2}{*}{ Total } & Count & $273(75 \%)$ & $91(25 \%)$ & 364 & 100 \\
\hline & $\begin{array}{l}\text { Expected } \\
\text { Count }\end{array}$ & 273.0(75\% & $91.0(25 \%)$ & 364 & 100.0 \\
\hline
\end{tabular}

Table 3: Relationship between Institution and Information needs area - Development of information search skills

Crosstab

\begin{tabular}{|c|c|c|c|c|c|}
\hline \multirow[b]{2}{*}{ Institutions } & & \multicolumn{2}{|c|}{$\begin{array}{l}\text { Information needs area - } \\
\text { Subject relating to study }\end{array}$} & \multirow[b]{2}{*}{ Total } & \multirow[b]{2}{*}{$\begin{array}{l}\% \text { of } \\
\text { Total }\end{array}$} \\
\hline & & Yes & No & & \\
\hline \multirow[t]{2}{*}{\begin{tabular}{|l|}
$\begin{array}{l}\text { UB } \\
\text { (Home- } \\
\text { based) }\end{array}$ \\
\end{tabular}} & Count & $\mathbf{5 7}(58.2 \%)$ & $\begin{array}{r}\mathbf{4 1}(41.8 \% \\
)\end{array}$ & 98 & 26.9 \\
\hline & $\begin{array}{l}\text { Expected } \\
\text { Count }\end{array}$ & 49.8(50.8\%) & $\begin{array}{r}48.2(49.2 \\
\%)\end{array}$ & 98.0 & 26.9 \\
\hline \multirow[t]{2}{*}{$\begin{array}{l}\text { UNISA } \\
\text { (Cross- } \\
\text { border) } \\
\end{array}$} & Count & $\mathbf{6 1}(38.6 \%)$ & $\begin{array}{r}97(61.4 \% \\
)\end{array}$ & 158 & 43.4 \\
\hline & $\begin{array}{l}\text { Expected } \\
\text { Count } \\
\end{array}$ & $\mathbf{8 0 . 3}(50.8 \%)$ & $\begin{array}{r}77.7(49.2 \\
\%) \\
\end{array}$ & 158.0 & 43.4 \\
\hline \multirow[t]{2}{*}{$\begin{array}{l}\text { MANCOSA } \\
\text { (Cross- } \\
\text { border) }\end{array}$} & Count & $28(62.2 \%)$ & $\begin{array}{r}\mathbf{1 7}(37.8 \% \\
)\end{array}$ & 45 & 12.4 \\
\hline & $\begin{array}{l}\text { Expected } \\
\text { Count } \\
\end{array}$ & $22.9(50.9 \%)$ & $\begin{array}{r}22.1(49.1 \\
\%) \\
\end{array}$ & 45.0 & 12.4 \\
\hline \multirow[t]{2}{*}{$\begin{array}{l}\text { UD } \\
\text { (Cross- } \\
\text { border) } \\
\end{array}$} & Count & $\mathbf{3 9}(61.9 \%)$ & $\begin{array}{r}\mathbf{2 4}(38.1 \% \\
)\end{array}$ & 63 & 17.3 \\
\hline & $\begin{array}{l}\text { Expected } \\
\text { Count }\end{array}$ & 32.0(50.8\%) & $\begin{array}{r}\text { 31.0(49.2 } \\
\%) \\
\end{array}$ & 63.0 & 17.3 \\
\hline \multirow[t]{2}{*}{ Total } & Count & $\mathbf{1 8 5}(50.8 \%)$ & $\begin{array}{r}\mathbf{1 7 9}(49.2 \\
\%) \\
\end{array}$ & 364 & 100 \\
\hline & $\begin{array}{l}\text { Expected } \\
\text { Count }\end{array}$ & 185.0(50.8\% & $\begin{array}{l}\mathbf{1 7 9 . 0}(49 . \\
2 \%\end{array}$ & 364.0 & 100.0 \\
\hline
\end{tabular}


Table 4: Relationship between Institution and Information needs area - Tests, examinations and residential sessions/periods

Crosstab

\begin{tabular}{|c|c|c|c|c|c|}
\hline \multirow[b]{2}{*}{ Institutions } & & \multicolumn{2}{|c|}{$\begin{array}{l}\text { Information needs area - } \\
\text { Tests, examinations and } \\
\text { residential } \\
\text { sessions/periods }\end{array}$} & \multirow[b]{2}{*}{ Total } & \multirow[b]{2}{*}{$\begin{array}{l}\% \text { of } \\
\text { Total }\end{array}$} \\
\hline & & Yes & No & & \\
\hline $\begin{array}{l}\text { UB } \\
\text { (Home- } \\
\text { based) }\end{array}$ & Count & $\begin{array}{c}\mathbf{7 8}(79.6 \% \\
)\end{array}$ & $\mathbf{2 0}(20.4 \%)$ & 98 & 26.9 \\
\hline & $\begin{array}{l}\text { Expected } \\
\text { Count }\end{array}$ & $\begin{array}{c}\text { 50.6(51.6 } \\
\%)\end{array}$ & $\begin{array}{c}\mathbf{4 7 . 4}(48.4 \% \\
)\end{array}$ & 98.0 & 26.9 \\
\hline $\begin{array}{l}\text { UNISA } \\
\text { (Cross- } \\
\text { border) }\end{array}$ & Count & $\begin{array}{c}\mathbf{8 1}(51.3 \% \\
)\end{array}$ & $77(48.7 \%)$ & 158 & 43.4 \\
\hline & $\begin{array}{l}\text { Expected } \\
\text { Count }\end{array}$ & $\begin{array}{c}\text { 81.6(51.6 } \\
\%)\end{array}$ & $\begin{array}{c}\text { 76.4(48.4\% } \\
\text { ( }\end{array}$ & 158.0 & 43.4 \\
\hline $\begin{array}{l}\text { MANC } \\
\text { OSA } \\
\text { (Cross- } \\
\text { border) }\end{array}$ & Count & $\begin{array}{c}\mathbf{2 0}(44.4 \% \\
)\end{array}$ & $25(55.6 \%)$ & 45 & 12.4 \\
\hline & $\begin{array}{l}\text { Expected } \\
\text { Count }\end{array}$ & $\begin{array}{c}\text { 23.2(51.6 } \\
\%)\end{array}$ & $\begin{array}{c}\text { 21.8 } \\
(48.4 \%\end{array}$ & 45.0 & 12.4 \\
\hline $\begin{array}{l}\text { UD } \\
\text { (Cross- } \\
\text { border) }\end{array}$ & Count & $\mathbf{9}(14.3 \%)$ & $\mathbf{5 4}(85.7 \%)$ & 63 & 17.3 \\
\hline & $\begin{array}{l}\text { Expected } \\
\text { Count }\end{array}$ & $\begin{array}{c}\text { 32.5(51.6 } \\
\%)\end{array}$ & $\begin{array}{c}\text { 30.5 } \\
\text { (48.4\% }\end{array}$ & 63.0 & 17.3 \\
\hline Total & Count & $\begin{array}{c}\text { 188(51.6 } \\
\%)\end{array}$ & $\begin{array}{c}\mathbf{1 7 6}(48.4 \% \\
)\end{array}$ & 364 & 100 \\
\hline & $\begin{array}{l}\text { Expected } \\
\text { Count }\end{array}$ & $\begin{array}{c}188.0(51 . \\
6 \%\end{array}$ & $\begin{array}{c}\text { 176.0 }(48.4 \\
\%\end{array}$ & 364 & 100.0 \\
\hline
\end{tabular}

Table 5: Relationship between Institution and Information needs area - Access to a help line

Crosstab

\begin{tabular}{|c|c|c|c|c|c|}
\hline \multirow[b]{2}{*}{ Institutions } & & \multicolumn{2}{|c|}{$\begin{array}{l}\text { Information needs area - } \\
\text { Access to a help line }\end{array}$} & \multirow[b]{2}{*}{ Total } & \multirow[b]{2}{*}{$\begin{array}{l}\% \text { of } \\
\text { Total }\end{array}$} \\
\hline & & Yes & No & & \\
\hline $\begin{array}{l}\text { UB } \\
\text { (Home- } \\
\text { based) }\end{array}$ & Count & $\mathbf{4 2}(42.9 \%)$ & $56(57.1 \%)$ & 98 & 26.9 \\
\hline & $\begin{array}{l}\text { Expected } \\
\text { Count }\end{array}$ & $\begin{array}{r}\mathbf{4 0 . 4}(41.2 \\
\%)\end{array}$ & $\begin{array}{r}\mathbf{5 7 . 6}(58.8 \\
\%)\end{array}$ & 98.0 & 26.9 \\
\hline \multirow[t]{2}{*}{$\begin{array}{l}\text { UNISA } \\
\text { (Cross- } \\
\text { border) }\end{array}$} & Count & $70(44.3 \%)$ & $\mathbf{8 8}(55.7 \%)$ & 158 & 43.4 \\
\hline & $\begin{array}{l}\text { Expected } \\
\text { Count }\end{array}$ & $\begin{array}{r}\text { 65.1(41.2 } \\
\%) \\
\end{array}$ & $\begin{array}{r}\text { 92.9(58.8 } \\
\%) \\
\end{array}$ & 158.0 & 43.4 \\
\hline \multirow[t]{2}{*}{$\begin{array}{l}\text { MANCO } \\
\text { SA } \\
\text { (Cross- } \\
\text { border) }\end{array}$} & Count & $22(48.9 \%)$ & $\mathbf{2 3}(51.1 \%)$ & 45 & 12.4 \\
\hline & $\begin{array}{l}\text { Expected } \\
\text { Count }\end{array}$ & $\begin{array}{r}\mathbf{1 8 . 5}(41.1 \\
\%)\end{array}$ & $\begin{array}{r}\mathbf{2 6 . 5}(58.9 \\
\%)\end{array}$ & 45.0 & 12.4 \\
\hline \multirow[t]{2}{*}{$\begin{array}{l}\text { UD } \\
\text { (Cross- } \\
\text { border) } \\
\end{array}$} & Count & $\mathbf{1 6}(25.4 \%)$ & $47(74.6 \%)$ & 63 & 17.3 \\
\hline & $\begin{array}{l}\text { Expected } \\
\text { Count }\end{array}$ & $\begin{array}{r}26.0(41.3 \\
\%) \\
\end{array}$ & $\begin{array}{r}37.0(58.7 \\
\%)\end{array}$ & 63 & 17.3 \\
\hline \multirow[t]{2}{*}{ Total } & Count & $\begin{array}{r}\text { 150(41.2\% } \\
)\end{array}$ & $\begin{array}{r}\mathbf{2 1 4}(58.8 \% \\
) \\
\end{array}$ & 364 & 100 \\
\hline & $\begin{array}{l}\text { Expected } \\
\text { Count }\end{array}$ & $\begin{array}{r}\mathbf{1 5 0 . 0}(41.2 \\
\% \\
\end{array}$ & $\begin{array}{r}214.0(58.8 \\
\% \\
\end{array}$ & 364.0 & 100.0 \\
\hline
\end{tabular}

Table 6: Relationship between Institution and Information needs area-Making info based decisions

Crosstab

\begin{tabular}{|c|c|c|c|c|c|}
\hline \multirow[b]{2}{*}{ Institutions } & & \multicolumn{2}{|c|}{$\begin{array}{c}\text { Information needs area - } \\
\text { Making info based decisions }\end{array}$} & \multirow[b]{2}{*}{ Total } & \multirow{2}{*}{$\begin{array}{l}\% \text { of } \\
\text { Total }\end{array}$} \\
\hline & & Yes & No & & \\
\hline \multirow[t]{2}{*}{\begin{tabular}{|l|} 
UB \\
(Home- \\
based)
\end{tabular}} & Count & $\mathbf{2 4}(24.5 \%)$ & $\mathbf{7 4}(75.5 \%)$ & 98 & 26.9 \\
\hline & $\begin{array}{l}\text { Expected } \\
\text { Count }\end{array}$ & 30.7(31.3\%) & $\mathbf{6 7 . 3}(68.7 \%)$ & 98.0 & 26.9 \\
\hline \multirow[t]{2}{*}{$\begin{array}{l}\text { UNISA } \\
\text { (Cross- } \\
\text { border) }\end{array}$} & Count & $\mathbf{4 5}(28.5 \%)$ & $\mathbf{1 1 3}(71.5 \%)$ & 158 & 43.4 \\
\hline & $\begin{array}{l}\text { Expected } \\
\text { Count } \\
\end{array}$ & $\mathbf{4 9 . 5}(31.3 \%)$ & $\begin{array}{c}\mathbf{1 0 8 . 5}(68.7 \% \\
)\end{array}$ & 158.0 & 43.4 \\
\hline \multirow[t]{2}{*}{$\begin{array}{l}\text { MANCOSA } \\
\text { (Cross- } \\
\text { border) }\end{array}$} & Count & $18(40 \%)$ & $27(60 \%)$ & 45 & 12.4 \\
\hline & $\begin{array}{l}\text { Expected } \\
\text { Count }\end{array}$ & $\mathbf{1 4 . 1}(31.3 \%)$ & $\mathbf{3 0 . 9}(68.7 \%)$ & 45.0 & 12.4 \\
\hline \multirow[t]{2}{*}{$\begin{array}{l}\text { UD } \\
\text { (Cross- } \\
\text { border) } \\
\end{array}$} & Count & $27(42.9 \%)$ & 36(57.1\%) & 63 & 17.3 \\
\hline & $\begin{array}{l}\text { Expected } \\
\text { Count }\end{array}$ & 19.7(31.3\%) & $\mathbf{4 3 . 3}(68.7 \%)$ & 63.0 & 17.3 \\
\hline \multirow[t]{2}{*}{ Total } & Count & $\mathbf{1 1 4}(31.3 \%)$ & $250(68.7 \%)$ & 364 & 100 \\
\hline & $\begin{array}{l}\text { Expected } \\
\text { Count }\end{array}$ & $114.0(31.3 \%$ & $250.0(68.7 \%$ & 364.0 & 100.0 \\
\hline
\end{tabular}

\section{Discussion}

From the data obtained, there were two major categories of information needs that respondents clearly indicated. These needs were: information in respect of subjects relating to courses of study, and the use of information and communication technologies (ICTs) (indicated by 75 and 60 percent of respondents respectively). This first result confirms the findings of Oladokun and Aina [3] in a separate study conducted on the continuing education students of the University of Botswana, where they reported that $95 \%$ of respondents stated that subjects relating to their course of study, was their main information need area. Similarly, the $60 \%$ of respondents who claimed the use of ICTs as their major information need area in this study appears to be in tandem with the outcome of Rowland and Rubbert's [5] study in the UK. The result in [5] shows that the information needs and practices of part-time, distance-learning and mature students in a lifelong learning environment have been rapidly transformed by the use of ICT in the higher education sector. While they assert that even though electronic facilities make information gathering easier for part-time and distance-learning students, there is still a long way to go until institutional 
information services are optimised in the HE sector. Two other information need areas that were indicated by about half of the respondents in the current study were information on tests, examinations and residential sessions/periods (51.6\% of respondents) and the development of information searching skills (50.8\% of respondents).

A study in [8] had shown that location of students contributes to the interest of distance learners in having information need on test, examinations and residential sessions/periods. The result of the study shows that more respondents from the village (rural area) than expected indicated that information on tests, examinations and residential sessions was a need area for them; whereas less respondents from the metropolitan areas (city and town) than expected said 'no' to information on tests, examination and residential sessions as a need area. The finding seems to suggest that respondents in the village and other rural locations are somewhat disadvantaged about information on tests, examinations and residential sessions than respondents in urban areas who have better access to information on the need area by virtue of the close proximity to their institutions or agents of their institutions, which they enjoy.

Other information need areas indicated by less than half of the respondents in this study include: access to a help line $(41.2 \%)$, making informationbased decisions (31.3\%); and the specialized information $(29.7 \%)$. Though these information need areas did not attract a majority of the total respondents, they are also significant. A distance learner would naturally want to bridge the gap created by distance delivery mode of education. Hence, if there is an access to a help line that is probably toll free, a distance learner would find it attractive. It naturally should also be expected that a student involved in self directed learning as distance education would want to make information-based decisions. Indeed, [1] had asserted that making sound and information-based decisions is one of the basic information services that distance learners need.

The study also found that majority of respondents $(77.7 \%)$ would require information to write assignments, while $75 \%$ of them wanted materials to study and prepare for tests and examinations. Information needs for course-related purposes were mentioned by $67 \%$ of the respondents. These are natural information areas expected of probably all the students, especially, distance learners. It therefore is baffling that the result did not record a hundred percent on each of the areas.

By and large, the distance learners of Botswana have shown from the findings, that information on subjects of their course of study, how to use the ICT, write assignment and study to prepare for test and examination topped the list in their scale of information needs preference. The use of ICT in particular shows the consciousness of the learners that the existing distance or gap between them and their institution in relation to their studies can be bridged by the use of ICT. The findings further show that these (distance) learners would not give high premium to the need for specialized information or even access to a help line in as much as they could have materials in subjects/courses of study and how to use the ICT. It is also significant to note that the distance learners would need to be equipped or developed with information searching skills. This implies the need to train and equip the distance learners with information literacy skills (ILS) so that they could operate independently and effectively in their self directed learning programme. As already noted, a sizeable number of distance learners would want to be appropriately informed on the periods of tests, examination and residential sessions, possibly well ahead of time. It should be noted that residential session especially is a period distance learners would not want to miss. It is a period they meet face-to-face with their tutors - when they could ask questions and seek clarification on topics or issues they were not too clear about in their private study. Residential sessions could be said to bring some element of human face to the seemingly faceless system of education found in distance learning. If residential session would assist them in their course of study, distance learners will be ready for it. This seems to be in line with the result of the investigation in [4], which notes that Sandwich and Part-Time Students would need information on their course of study among other varieties.

The study found that more urban-based distance learners and less rural based (village) respondents than expected affirmed that they make information-based decisions. It could be suggested that this occurs because information is much more available and easily accessible in the cities and towns than in the villages. This shows that information-rich and information-poor environments may define the types of decision the distance learners make. Generally, distance learners should be assisted to be critical thinkers and therefore will need to be able to make information-based decisions irrespective of where they are located - whether they are urban- or rural-based.

The study also found that location was significantly related to information needs in the areas of "writing tests, examinations and doing residential sessions", with more respondents from the rural areas than expected indicating that they needed information on tests, examinations and residential sessions. Conversely, less respondents from the urban areas than expected indicated the need for such information. This also seems to confirm the existence of information inadequacy in the rural areas as against what obtains in the urban areas where there is preponderance of information resources and services, even as the urban based 
students also enjoy proximity to their institutions or agents of their institutions.

As noted above, the study has clearly established that institution of respondents was significantly related to some information need areas, namely: "subjects relating to their course of study" $\left(\mathrm{X}^{2}=\right.$ 9.092, df = 3, p <.05); "development of information search skills" ( $\mathrm{X}^{2}=16.981$, df $\left.=3, \mathrm{p}<.05\right)$; "tests, examinations and residential sessions/periods" $\left(\mathrm{X}^{2}=\right.$ 66.803, df $=3, \mathrm{p}<.05)$; "access to a help line" $\left(\mathrm{X}^{2}=\right.$ 8.332 , df $=3, \mathrm{p}<.05)$ and "making informationbased decisions" $\left(\mathrm{X}^{2}=8.192\right.$, df $\left.=3, \mathrm{p}<.05\right)$. By this, the finding has clearly demonstrated the areas of information needs of distance learners which this study was meant to uncover.

In their suggestions of what should constitute the information needs of distance learners, a number of authors have expressed views. For instance, Kascus and Aguilar [9] stress that the following requirements constitute the basic information needs of distance learners: access to adequate facilities; core collections; professional library staff; reserve reading collections; and supplementary materials. Others authors as indicated in [1], [2], [3], [7], among others are significant in defining the various and related information needs of distance learners and are relevant to this study. Of particular relevance to distance learners in Botswana are the information needs as expressed by the Commonwealth of Learning (COL). COL [1] affirms that the basic information services that distance learners need are access to information resources, such as texts, supplementary reading and reference services; learning how to find the information they need from the information that is available and developing ways to apply the information gleaned and to make sound, information-based decisions. It is however observed in this study that the latter i.e. making informationbased decisions, was found more among higher degree pursuing learners from University of Derby (UD) and the Management College of Southern Africa (MANCOSA). Others should also be able to make sound and information based decisions as well.

\section{Conclusion and Recommendations}

The findings have clearly provided hints to the providers of distance education on the likely information topography in which distance learners operate generally in Africa and Botswana in particular. The findings have also attempted to prepare the minds of distance teaching institutions, be it local, foreign or cross border, to know the areas of needs of distance learners. The possibly hitherto unknown information needs of the tertiary level distance learners in Botswana including the experience of cross-border distance education students have been brought open by the study. The awareness of the information needs of distance learners heralded by this study is capable of equipping the providers and other stakeholders of distance education on the best way to assist the tertiary level distance learners in Botswana. In general the study findings indicate that:

- Information on subjects of their course of study, how to use the ICT, to write assignment and study to prepare for test and examination top the list in their scale of information preference of distance learners in Botswana.

- The distance learners would need to be equipped or developed with information searching skills.

- More urban-based distance learners and less rural based (village) respondents than expected affirmed that they make information-based decisions.

- Location was significantly related to the use of the Internet as an information source - more urban-based and less rural-dwelling respondents than expected used the Internet.

- The information needs of the distance learners in Botswana are significantly unmet.

The recommendations of the study would naturally stem from the findings. For instance, arising from the needs, the findings revealed that "the distance learners would need to be equipped or developed with information searching skills". In order to do this, teaching of information and literacy skills (ILS) will assist the students to be equipped the searching skills.

In view of the unrelenting evolution of modern technologies, conscious and continuing effort should be made to train distance learners in computing and information literacy skills.

With the establishment of the fact that "more urban-based distance learners and less rural based (village) respondents than expected affirmed that they make information-based decisions", the rural based learners too deserved to be assisted to make information-based decisions. Some training on critical thinking coupled with the training on ILS will assist the students in being able to make information based decisions.

With evidence that the information needs of the distance learners, especially the rural-based ones in Botswana, are significantly unmet, the spread or various locations of the distance learners of any particular institutions should be looked into with a view to adequately cater for them both physically 
and electronically. For now, the University of Botswana Library (UBL) and its branches appear to be a significant and extensive adjunct helping to meet the information needs of the learners including the cross border students in Botswana. It is therefore suggested that the cross-border institutions operating in Botswana should work out a more convenient arrangement with the UBL.

Apart from the 'home-based' distance learning programs, evidence of the escalating existence and provision of cross border or transnational, private and 'for-profit' tertiary education now abounds in Botswana. Whilst the initiation of cross-border institutions is an effort geared towards meeting the ever increasing demand for tertiary education in the country, a note of caution should be sounded! The results of the study have implications for quality assurance in the provision and, or practice of open and distance education in Botswana; and the need for enhancement of motivation for distance learners, their learning process and learning success. A perusal of the report of the Republic of Botswana on National Commission on Education [10] reveals a gap in the recommendation made on the provision of tertiary distance education in Botswana. Even though the Commission regarded distance education as an integral part of the national education system, the report omitted the incursion of 'borderless', crossborder or transnational education in the national scene. In this respect, a clear cut policy detailing the expectations of the government of Botswana from any distance teaching institutions of both local and foreign extractions should be clearly spelt out. Provision should be made for the establishment of a National Advertiser (Agency) to guide the potential distance learners on the approved distance teaching institutions and, or programmes in the country

\section{References}

[1] Commonwealth of Learning (COL) (2003). Developing library and information services for distance education. Available online at http://www.col.org/colweb/site/pid/3131 Retrieved 10 August, 2014

[2] Singh, B. K. 2002. Library Services to Distance Learners: A Study of Kota Open University. Paper presented at the AAOU Pre-Conference Seminar on Outreach Library Services for Distance Learners. Available: http://www.ignou.ac.in/aaou-pre/B K\%20Singh.htm Retrieved 21 June, 2014.

[3] Oladokun, O. S. and Aina, L. O. (2009) Library and information needs and barriers to the use of information sources by continuing education students at the University of Botswana. Information Development, 25 (4), pp. 43-49. Available online at http://idv.sagepub.com/content/25/1/43.full.pdf+html
[4] Adesoye, A.A. and Amusa, O.I. (2011). Investigating the Information Needs of Sandwich and Part-Time Students of Two Public Universities in Ogun State, Nigeria. http://unllib.unl.edu/LPP/ Library Philosophy and Practice (2011). Available online at http://www.webpages.uidaho.edu/ mbolin /adesoye-amusa.htm

[5] Rowland, F. and Rubbert, I. (2001),"An evaluation of the information needs and practices of part-time and distance-learning students in the context of educational and social change through lifelong learning", Journal of Documentation, Vol. 57 Iss 6 pp. 741 - 762 Available online at http://www.emeraldinsight.com/doi/pdfplus/10.1108/ EUM0000000007105

[6] Oladokun, O. (2014). The Information Environment of Distance Learners: A Literature Review. Creative Education, Vol. 5 (5), 303 - 317 Available online at DOI: $10.4236 /$ ce.2014.55040

[7] Jagannathan, Neela (1998). Libraries in distance teaching University. In: M.K. Jain et al. (Eds.) 50 Years Library and Information Services in India, Delhi: Shipra Publications.

[8] Oladokun, O. (2012). Locational dynamics influencing the information environment of distance learners in Botswana. In Paul Birevu Muyinda (Ed.) Distance Education Croatia: Intech

[9] Kascus M. and. Aguilar W. (1988). Providing library support to off-campus programmes. College and Research Libraries 49, (1) 29 - 37.

[10] Republic of Botswana (1993). Report of the National Commission on Education. Gaborone: Government Printer. 